\title{
Lack of Social Security of The Workers of Gastronomic Business in Poland Due To The Epidemic Covid-19
}

\author{
DOI: $10.26466 /$ opus.886592
}

\begin{abstract}
*
\section{Artur Michal Banaszak *}

* Alcide De Gasperi University of Euroregional Economy in Jozefów - Poland E-Mail: artur.banaszak@wsge.edu.pl

ORCID: 0000-0003-3657-3866
\end{abstract}

\begin{abstract}
The social security, understood as a state where a person has the opportunity to live, survive and develop, is a very important issue. To ensure this state to security, certain activities of the states and other bodies are necessary. Those activities should be focused on the process of satisfactions of different human needs all the time even in the time of crises such the state of pandemic which is faced right now. Because of the problems related to covid-19, the security, especially social security of many people is at risk. One of the groups which is particularly affected by epidemic are people working in gastronomic industry (workers of pubs, bars, and restaurants). The goal of this article is to show that people hired in gastronomic industry may have problem with the sense of social security due to current humanitarian crisis. Some analyzes of the current situation of this industry will be made. Also, we would like to show that the help provided by state social policy within anti-covid shields are not sufficient and proper. Some international background and scenario will be given but mainly, the article will focus on the situation in Poland.
\end{abstract}

Keywords: Covid-19 pandemic, social security, gastronomic industry, anti-covid shields 


\section{COVID-19 Salgını Nedeniyle Polonya'daki Gastronomi İşinde Çalışan İşçilerin Sosyal Güvenlik Eksikliği}

Öz

Kişinin yaşama, yaşama ve gelişme imkanına sahip olduğu bir devlet olarak anlaşılan sosyal güvenlik çok önemli bir konudur. Bu devletin güvenliğini sağlamak için, devletlerin ve diğer organların belirli faaliyetleri gereklidir. Bu faaliyetler, şu anda karşılaşılan pandemi durumu gibi kriz zamanlarında bile her zaman farklı insan ihtiyaçlarının karşılanması sürecine odaklanmalıdır. COVID-19 ile ilgili sorunlar nedeniyle birçok kişinin güvenliği, özellikle de sosyal güvenliği risk altındadır. Salgından özellikle etkilenen gruplardan biri gastronomi endüstrisinde çalışan kişilerdir (pub, bar ve restoran çalışanları). Bu makalenin amacı, gastronomi sektöründe işe alınan kişilerin mevcut insani kriz nedeniyle sosyal güvenlik anlamında sorun yaşayabileceğini göstermektir. Bu sektörün mevcut durumuna ilişkin bazı analizler yapılacaktır. Ayrıca, anti-covid kalkanları içinde devletin sosyal politikasının să̆ladı̆̆ yardımın yeterli ve uygun olmadığııı göstermek istiyoruz. Bazı uluslararası arka plan ve senaryolar verilecek, ancak esas olarak makale Polonya'daki duruma odaklanacaktır.

Anahtar Kelimeler: Covid-19 pandemisi, sosyal güvenlik, gastronomi endüstrisi, antikovid kalkanları 


\section{Introduction}

The entire world is facing a very difficult situation due to the state of pandemic of coronavirus disease 2019. This infectious disease appeared in China, where the illness officially was recorded for the first time on $10^{\text {th }}$ December 10, 2019. Then, the first case outside China was noticed in Thailand on $13^{\text {th }}$ January 2020. World Health Organization called the state of epidemic threat on global level on $30^{\text {th }}$ January 2020 and due to increase of cases all over the world - on $11^{\text {th }}$ March, WHO called the state of pandemic (Wójcicka, 2020, p.416-417).

From this moment the virus was spreading vary fast. Hundreds, thousands, and millions of people have been infected. Covid-19 has also resulted in the deaths of many patients. During only one year, according to official data from $1^{\text {st }}$ December 2020, we have 70000000 corona-cases all over the world and 1500000 people died. Two hundred eighteen countries and territories are affected by virus. Three countries are touched the most by this disease - the USA - more 16000000 cases, India - almost 9800000 cases and Brazil - almost 6800000 cases. In the world's ranking Poland and Turkey are on a rather high position considering the population size - Turkey is $8^{\text {th }}$ with almost 1750000 cases and Poland is placed $14^{\text {th }}$ with 1100000 cases (Worldometer, 2020).

In this very difficult time, the social security of many people all over the world is at risk. They are facing different issues which interfere with meeting their needs. It means that they have problem to live, survive and develop. Therefore, the extraordinary actions and activities should be taken to help people with those problems. Every human being has the rights to satisfy their needs and to feel safe and secure, even, during the crises. One of the groups which is particularly affected by epidemic are people working in gastronomic industry - workers of pubs, bars, and restaurants.

The goal of this article is to present the situation of workers in gastronomic industry as well as to show some measures taken by state in order to solve the problems. The hypothesis was made that people who are hired in this sector may have problem with the sense of social security due to current humanitarian crisis. Some analyzes of the current situation of this industry will be made. Also, we would like to prove that the help provided by state social 
policy within anti-covid19 shields are not sufficient and proper. Some international background and scenario will be given but mainly, the article will focus on the situation in Poland.

\section{Satisfaction Of Human Needs As The Condition Of Social Security}

The social safety and security may be understood as a state in which individuals, groups of people as well as the entire society have possibility and opportunity to life, to survive, and to developed. The right to social security is guaranteed to every person in the different documents, rules and regulations related to human rights (Banaszak, 2018, pp.17-19). In order to ensure this state of security to the society, certain activities of the states and other bodies are necessary. Those activities should be focused on the process of satisfactions of different human needs.

The assistance in the process of satisfaction of human needs seems to be necessary and crucial. Living, surviving and personal and social development of human being are possible only if those human needs are satisfied. It is also the result of human rights people are entitled to (Sitek, 2016). The issue of human need can be described from the perspective of A. Maslow theory of needs. This America psychologist is proving that there are different level of needs starting from basic needs - physiological and security through psychological needs - belongingness, law, esteem, and on the self-fulfillment needs - self-actualization ending (Maslow, 1943). In order to have a decent and good life, all those needs to be satisfied.

In order to make this process possible, we need social policy, which is understood as the activities of the state and other bodies focused on satisfaction of human need and at the same time to make individuals and entire society feel safe and secure. Even in the time of crises, such as the state of pandemic related to coronavirus, people must feel safe and secure - they must be able to live and to survive as well as to developed and improve their lives. Therefore, because the situation is extraordinary, some of special activities are necessary.

The crises caused by coronavirus touched every area of human life, in every country. It also impacts different areas of economy. One of the sectors of economy which was badly impact by coronavirus is hospitality and tourism industry, including gastronomic sector. Because of that restrictions focus 
on fight with the spread of virus, many places in gastronomic sectors were closed and pushed to limit or stop operations. Therefore, people who were hired in this industry could not work and at the same time they were not earning. It means that they start to face problems and the satisfaction of their different need was disturbed.

\section{Gastronomic Sector During Pandemic State}

With the spread of virus and the information about the higher numbers of people infected or dying due to covid-19, the particular governments started to implement some restrictions and limitations. The hospitality industry, including gastronomic sector was one of the first area touched with these restrictions. Hotels, restaurants, pubs, bars and other pleases serving food were closed or their operation was limited. People stopped to travel, and they were staying home so they were not eating out. Because of such situation, the gastronomic business stopped making money and owners as well as employees were deprived of source of income.

The problem is not only related to different restrictions which were implemented in different countries and regions but also in customers minds. Many people are afraid to travel or to go eating out. Some findings are shown that more than $50 \%$ customers are not willing to go to restaurant or to travel and stay in hotels (Gursoy D., C., Chi, 2000).

According to the World Travel and Tourism Council, the estimations based on analyzes of II quarter of 2020: April - June shows that the tourism industry accounts for $10 \%$ of the world's GDP and jobs would by decreased by about $25 \%$ in 2020 and it will lose about 50 million job places all over the world:

- 30 million job places lost in Asia,

- 7 million jobs places lost in Europe,

- 5 million job places lost in North and South Americas,

- 8 million job places lost in rest of the world.

According to this estimation and the statistical data, in these three months of second quarter of 2020, globally, it will be reduction in jobs of between $12 \%$ and $14 \%$ (Seifman, 2020).

Hospitality and tourism economy in every country has been harmed by pandemic. For example, in OECD countries, where tourism takes around 7\% 
of job place, the decline of international tourism in estimated in 2020 on the level of $60 \%$ or even $80 \%$ if there is no recovery before December 2020 . Hospitality sector is facing a lot of difficulties in some of the touristic European Union countries where the share of tourism employment represents $15.7 \%$ of total employment in Iceland, $13.5 \%$ in Spain, $10.3 \%$ in Ireland, $10.0 \%$ in Greece, and 9.8\% in Portugal. In the United Sates of America, in May 2020, around $52 \%$ of small businesses in tourism of hospitality sector were temporarily closed and $35,2 \%$ of them inform about decrease of employment. Another example is Coba region in Mexico, where tourism cover $80 \%$ of economy and the number of coming of international tourists went down by $93 \%$ in compere to last season (Seifman, 2020).

The situation of gastronomic industry in Poland is the same as everywhere else. When we analyze the year 2020, we can divide it into three periods:

- first lockdown: from middle of March 2020 to end of May 2020,

- loosening of the restrictions during summer holydays: from June 2020 to September 2020,

- second lockdown: from the beginning of October till now.

The very first case of coronavirus was announced in Poland on $4^{\text {th }}$ March 2020. Then, the numbers started to grow, and the government called the state of epidemic threat on $14^{\text {th }}$ March 2020 and after one week, the state of epidemic o 20 $0^{\text {th }}$ March 2020. Together with this, many restrictions and limitation were introduced which touched many areas of business, including the gastronomic sector.

Based on governmental regulation, the entire gastronomic sector was closed from $14^{\text {th }}$ March 2020. Firstly, it was for 14 days but then, subsequent regulations extended this time. The restaurants, pubs, bars, and clubs had to stop their normal operation. Only delivery of food was possible. For many businesses it was problematic solution. Some of them were not adopted to this kind of activities. In the case of others, such as fine-dining restaurants, the delivery was not working well because the clients did not which to order expensive dishes in plastic boxes (Tomaszewska-Bolałek, 2020). The situation lasted until second part of May 2020. First of all, from $18^{\text {th }}$ May 2020, the government agreed to open the gastronomic sector but with many restrictions related to sanitary regime and the limits of quests in restaurants. Then, from $30^{\text {th }} 2020$, the limit on the number of guests has been lifted but the businesses had to work in special sanitary regime. 
It is obvious that these four months cost a lot of problems. People were not eating out, so the revenues and profits of the sector went down. In addition, people were not organizing weddings, anniversaries as well as other family gatherings and social events which normally gives good business to the gastronomic sector. As the consequences, some of the businesses called the bankruptcy and many people lost their jobs.

The situation started to normalize during summer holidays. The number of corona-cases went down, and people tried to have normal life. During summer, Polish people traveled and used restaurants, pubs or bars and well as they attended different types of social family or cultural events. But still, the situation was not perfect and if we compere with the same period from 2019 , the gastronomic sector noticed decreased of profit. It was due to the fact that some people were still afraid to travel or going out to the places with bigger gathering. Also, some people due to economic problem stayed home. They lost incomes so they tried to satisfy basic needs first or even they have some extra recourse they want to save it because they were not sure of the scenario for the future.

In addition, less foreigners were traveling to Poland. In first half of 2020, it was less by $41,3 \%$ foreigners travel to Poland and they spent less money by $43,7 \%$ in Poland buying goods and services. Poland is not a huge tourist destination but still, the profit from abroad travelers and tourists is not small (Główny Urząd Statystyczny, 2020).

After summer holidays, most of the people came back to work and the children went back to schools. Together with the autumn, we faces the second wave of the coronavirus covid-19 and the fast increase of the daily cases. In Poland, the numbers started to grow from few hundred up to almost 30000 cases daily. Also, the number of deaths went up. Therefore, the government gradually introduced restrictions and limitations and the gastronomic sector was the first one to be touched by these regulations.

Some restriction and limitation were introduced from the beginning of October 2020 due to the fact of having red and yellow zones in Poland. For example, the gastronomic sector, including restaurants, pubs, bars, clubs could operate only until $9 \mathrm{pm}$. Most of the people wants to spend evening or even night having fun, eating out or meeting with friend and family. Closing the operation at $9 \mathrm{pm}$ meant that the business again faced serious situation. 
The next restrictions have been introduced since $24^{\text {th }}$ October 2020. The government made the decision about closing the restaurants, pubs, bars, and clubs. They could prepare the food and sell it only for pick up or delivery. Again, they cannot organize events and gatherings and they are not able to operate in normal way. The restrictions introduced in October are still in power and cost huge losses for gastronomic sectors. Again, some of the businesses are calling bankruptcy and workers are losing jobs (Szostak, 2020).

Right now, it the middle of December, the gastronomic sector is in very dramatic situation. Many restaurants, pubs, bars and clubs called bankruptcy. According to Polish Statistical Office, the employment in Poland went down by $3,2 \%$ in the entire economy and by $12,8 \%$ in gastronomic sector. This data is from May 2020, so it is not covering the second lockdown scenario. We can assume that now it is even worst (Główny Urząd Statystyczny, 2020).

Due to the first lockdown which we faced from March to May, the economic situation of gastronomic sector worsened. Then, because of summer holidays and the introduction of tourist voucher of 500 pln - 110 euro, we could notice some of the improvements. But since September and especially due to second lockdown, the situation is gradually getting worse.

\section{Governmental Assistance And The Gastronomic Sector}

The gastronomic sector faced a very difficult situation due to current humanitarian crisis. People who are being employed in this industry are not able to cope with this problem by themselves. Therefore the help and assistance of governments as well as other organization in necessary.

The World Travel and Tourism Council is calling governments of different countries to take special and extraordinary steps to help the sector to overcome crises. The entire tourism and hospitality industry need to be helped. The WTTC aske government not only to give some direct help to the sector but also to change some of the policy and rules to help this industry in future. Some of the suggestions are:

- to remove or simplify visas wherever possible which will increase of number of travelers and give extra profit to tourism sector and the gastronomic businesses,

- to cut travel taxes which lower cost of traveling and more people will make the decision to travel, 
- to introduce incentives which will help to make the tourist and hospitality sector more vital (Seifman, 2020).

Thinking about future is necessary but the entire sector, including the gastronomic industry need to be help right now. Therefore, different governments prepared different types of assistance to strengthen the economic situation of the countries and to save job place.

There are some examples of governmental action for tourism and hospitality sectors in different parts of the world. In the USA, the government implemented the Paycheck Protection Program with 659 billion US dollars. In Bhutan, the government decided to deferred tax payment to tourism and related sector until 31 $1^{\text {st }}$ December 2020. In Canada, the tourism and hospitality sector received the help of 85 billion Canadian dollars in liquidity support. In Italy, where the small individual hospitality businesses are bigger part of sector than huge chain companies, the government promised to pay $80 \%$ of total wages for the workers who lost their job. There is also the loan guarantee assistance as well as they launched the holiday voucher program called Bonus Vacanze. In Germany, there is no federal help, but each state is developing own assistance strategies. In the state of Baden-Wuerttemberg, the local government offered the help of 330 million euro for the hotel and catering trade (Seifman, 2020).

Also, some actions were taken by the government of Poland in this area. Together with the first lockdown, some regulations were introduced which were called anti-covid19 shields. According to date from the Polish government, in the first half of 2020, the government spent reasonable amount of money to help economy. There were:

- 23.9 billion PLN for the purpose of loans to Small and Medium size Enterprises with governmental guarantees,

- $\quad 17.0$ billion PLN for the exemption from social security contributions,

- 5.0 billion PLN for the shutdown subventions,

- 1.13 billion for EU financing for Small and Medium size Enterprises,

- 900 million PLN for tourist vouchers of which 233 million were used (Gov.pl, 2020)

The last initiate - tourist vouchers were given directly to tourism and hospitality industry. All families with children received a voucher with the 500 pln value for each child, which can be used to buy touristic service. The 
voucher is in digital version and the family can use it on the territory of Poland. It is valid until and of March 2022 (Ministerstwo Rozwoju Pracy i Technologii, 2020).

Next to the help, which was already granted, the government of Poland is promising also the assistance related to the second lockdown. They are planning to introduce new rules of the next anticovid19-shields. The first area of announced assistance is regarding co-financing of fixed costs for Small and Medium size Enterprises (SMEs). In this field, the Government will provide subsidies to companies under the Financial Shield of the Polish Development Fund in the amount of up to $70 \%$ of fixed costs not covered with revenues. The condition will be a $30 \%$ decrease in revenues compared to the same period in 2019 and this is the solution intended for the industries being subject to sanitary restrictions. The planned date of implementation of this regulation is by mid-December and real help - transfer the financial resource should start in January 2021. The second area of assistance is focused on co-financing for employment. They are planning to introduce shutdown payments extension for industries being subject to the restrictions of second lockdown. Also, the government is willing to extend the exemptions from social security contributions for industries affected by the lockdown (Gov.pl, 2020).

The third area of help is related to co-financing of the change in the scope of activities under the "Grants for business". The government understands that some of the companies from particularly harm sectors will be not able to operate anymore. Therefore, they want to help them to change the profile or a scope of business activities (Gov.pl, 2020).

It must be noticed that the government prepared some support for the companies touched by covid19. But in the case of gastronomic sector and the entire hospitality and tourism industry, this support not always has been helpful. There are so many reasons for such situation. First of all, some of the help is just promised not granted. Some of the payments are planned to be made in January. By this time, many restaurants, pubs, or clubs will be already bankrupt. Rent of the places, costs of hiring people and costs of materials take most of the profits. The gastronomic sector operates with very low margin of profits. Therefore, the decrease of sale will cost them bankruptcy. Also, People working in the gastronomic sector are proving that the process of applying and receiving the assistance is long, complicated, and difficult (Sąsiada, 2020). 
The financial help for the companies which decided to change the profile and the scope of business activities is also not suitable to save the gastronomic business and people who are hired in this sector. Somebody who is a cook, or a waiter will not become a driver of construction's worker in short time. Even when the owner decided to change the profile, those people who were working for him, will be staying without any job.

While we are talking about gastronomic sector in Poland, we have to noticed and point out one more thing. Some people working in gastronomic sector are hired as a part of grey economy. They have no contracts and they just work with cash payments. Gray economy itself is a wrong thing but because the sector is working on low profit margin, sometimes it is the only possibility to get the job. The problem is that is there are some employees who did not have job contract, none of the form of governmental assistance is useful for them.

\section{Gastronomic Sector's Employees And The Social Security Issues}

The analyzes of current situation in gastronomic sector as well as presentation of the very often unsuccessful forms of help and assistance offered or promised by the government proved that this part of the economy was strongly harmed and negatively touched by the coronavirus covid19. It touched people who were working in this sector.

Due to this crisis, the process of satisfaction of human needs is disturbed. Right now, many people are facing the problem with the satisfaction of even basic needs. The crises result in the situation where people have problem to survive and when their personal, social, and professional development is impossible. Therefore, they do not feel safe and secure in social sense.

The biggest problem of people working in gastronomic sector is that they lost their job, or they are in risk of losing the job. Without job and salary, they are not able to satisfy any of their needs. They will not be able to pay for food and accommodation and their sense of economic security will dropped down. They are not able to meet with friends and family, because of restriction or because they cannot afford it. If they do not have enough money to survive and to satisfy basic matters, such needs as prestige, feeling of accomplishment or achieving one's full potential including the creative activities are even hard to think. 
Also, they are not able to change the job, because the general economic situation is difficult and other sectors are not hiring people, especially those without proper qualifications. Therefore, those gastronomic sector's workers who are losing the job currently are at risk of being unemployed for longer periods.

In Poland, we have kind of unemployment insurance. But some of those workers are not even able to get support from unemployment funds because they were working without any contracts so, they cannot prove proper employment periods to be eligible for this help.

If those people are not able to secure even their basic needs, they have problem with survival as well as personal and professional development.

\section{Conclusion}

The economic situation in general is very difficult due to the crises related to pandemic of coronavirus. Many different industries and sectors were badly touched by this crisis. Many businesses and people related to them are in dramatic situation. The gastronomic sector - restaurants, pubs, bars, clubs as a part of hospitality and tourist industry faced very difficult situation everywhere in the world, and also in Poland. The first lockdown for March to May, then some limitation during summer holidays and current restriction called second lockdown caused that during big part of the year, those business were not able to act and operate on regular bases.

The coronavirus is killing people, but it must be said that is also killing the economy and in very special and negative way is killing the hospitality and tourism industry including gastronomic sector. People working in this sector are losing the jobs and the business in going down in huge scale due to the restrictions which were introduced by government in order to combat the spread of virus. Also, the general economic situation results that this industry will have problem with the recovery. Going to restaurants, ordering the food, using the catering, or organizing the meetings do not belong to the area of basic needs. People needs food but if they are in difficult economic situation, they are going to supermarkets buying products and prepare the food by themselves. They are not going to restaurants or pubs because they are afraid of virus or they cannot afford it. So even after pandemic, coming back to normal will be not easy job for gastronomic sector. 
This sector will need special help and special assistance in order to survive and recover. The sector as an important part of economy but also people who were part of those businesses need to be helped. Because the situation is extraordinary, the type of help must be special too. The assistance which was offer to this particular industry by the government of Poland seems not to be sufficient and proper. Therefore, it is necessary to develop and work some different ways. This help must be real and focused on the processes of satisfying human needs. This special support must be a part of prepared and wellorganized social policy. And what is important - the real help must be done as soon as possible which mans now. It cannot be done in the way, that restrictions are introduced in October ad the help is planned in January. Between October and January, many gastronomic businesses will be already gone and people who were working there will experience problems.

The issue of social security is a very important matter. It is about life, survival, and full development of human being. The necessary condition of getting this sense of social security is the possibility of satisfaction human needs. If a person is not able to do it, his or her social security is at risk. Right now, many employees of gastronomic sector feel the luck of social security.

\section{References}

Banaszak, A. (2018). Welfare as a form of ensuring the social safety of society and an effective and successful tool in election campaigns: Thoughts based on the situation in contemporary Poland. Regional Formulation and development studies, 3(26).

Główny Urząd Statystyczny (2020). Dane dla roku 2020. https://bdl.stat.gov.pl/BDL/pomoc/stanzasilenia?active $=3$ accessed on 05.11.2020.

Gov.pl (6th November 2020). Kolejny pakiet 10 dziatan antykryzysowych dla polskich firm. https:/www.gov.pl/web/koronawirus/kolejny-pakiet-10-dzialanantykryzysowych-dla-polskich-firm access on 07.11.2020

Gursoy D. and Chi, C. (2020). Effects of COVID-19 pandemic on hospitality industry: Review of the current situations and a research agenda. Journal of Hospitality Marketing $\mathcal{E}$ Management. 3(29), 527-529. https:/www.tandfonline.com/doi/full/10.1080/19368623.2020.1788231 access on 05.11.2020

Maslow, A. H. (1943). A theory of human motivation. Psychological Review, 50(4), 370-396.

Ministerstwo Rozwoju Pracy i Technologii (2020). Bon turystyczny. https://www.gov.pl/web/rozwoj-praca-technologia/bonturystyczny access on 05.11.2020. 
Sąsiada, T. (27th October 2020). Im rządowa pomocjuż się nie przyda. Restauracja kończy działalność przez nowe obostrzenia. Monay.pl. https://www.money.pl/gospodarka/im-rzadowa-pomoc-juz-nie-pomoze-restauracja-konczy-dzialalnoscprzez-nowe-obostrzenia-6569126160456480a.html access on 05.11.2020 .

Seifman, R. (4th September 2020). How COVID-19 Hits Hard the Hospitality Industry and What Can Be Done. Impakter. Available at. https://impakter.com/covid-hits-hospitality-industry access on 05.11.2020.

Sitek, M. (2016). Prawa (potrzeby) człowieka w ponowoczesności. Warszawa: C.H.Beck Publishing House.

Szostak, V. (23rd October 2020). Zamknięcie restauracji w pandemii. Gastronomia to setki tysięcy miejsc pracy: A nikt z nami nie rozmawia. Gazeta Wyborcza. https://poznan.wyborcza.pl/poznan/7,36001,26427133,restaurator-z-poznania-zamykajanas-nagle-od-jutra-kiedy.html access on 05.11.2020.

Tomaszewska-Bolalek, M. (2nd October 2020). Rewolucja zamiast ewolucji :Rzeczywistość dla sektora gastronomii jest miażdżąca. Forbes. https://www.forbes.pl/biznes/branza-gastronomiczna-w-czasie-koronawirusa-jak-radzi-sobie-w-2020roku/zqj10xs access on 05.11.2020.

Worldometer (2020). Covid 19 coronavirus pandemic. https://www.worldometers.info/coronavirus/?fbdid=IwAR1iLmrjfL9LhMPJupvrp9atSPja7Z--unWkZTp9Sb6dP6MdiYGA5UVS3U access on 01.12.2020

Wójcicka, A. (2020). Prawa cłowieka i obywatela w okresie pandemii koronawirusa w Polsce. State and Society facing pandemic (ed.) E. Burda, C. Lázaro Guillamón, M. Sitek. Bratysława: Camenius University Publishing House.

\section{Kaynakça Bilgisi / Citation Information}

Banazsak, A. M. (2021). Lack of social security of the workers of gastronomic business in Poland due to the epidemic Covid-19. OPUSInternational Journal of Society Researches, 17(Pandemi Özel Say1s1), 3185-3198. DOI: 10.26466/opus.886592 